\title{
A Critical Analysis of the Protection of Stakeholders' Interests under the South African Companies Act: (Part 2)
}

\author{
Linda Muswaka \\ Faculty of Law, North West University, South Africa \\ E-mail: leemuswaka@gmail.com
}

\section{Doi:10.5901/mjss.2014.v5n3p66}

\section{Abstract}

While the Companies Act 71 of 2008 does not provide for an explicit duty for directors to consider the interests of stakeholders, it may appear as if the shareholder value approach has become significantly more nuanced through the operation of other company law principles, such as the business judgment rule, the requirement for the appointment of a social and ethics committee, the remedies and the provision for the Memorandum of Incorporation as well as the link between governance and the law. This paper provides a critical analysis of these company law principles. The aim is to investigate to what extent these company law principles can be relied on as a means of guaranteeing the protection of stakeholders' interests. The paper concludes that stakeholders' interests are best protected where an explicit duty exists for directors to consider the interests of other stakeholders. A call for law reform is therefore made in this regard.

Keywords: Corporate Governance, Shareholders, Stakeholders, Directors

\section{Introduction}

To a certain extent, it may appear as if the shareholder primacy approach has become significantly more nuanced through the operation of other company law principles, such as the business judgment rule, the remedies and the provision for the Memorandum of Incorporation as well as the link between governance and the law. For instance, one may argue that the Companies Act allows for parties to guarantee the recognition and protection of stakeholder interests simply by including a clause in the Memorandum of Incorporation ${ }^{1}$ giving directors the duty to consider stakeholder interests. Furthermore, one may argue that the business judgment rule protects a board's decision to pursue not only financial but also social and environmental goals. While these arguments appear attractive, it is submitted that they are fraught with complexities as will be highlighted in the discussion below.

\section{The Argument on the Memorandum of Incorporation}

The MOI is defined in section 1 of the Companies Act as the document, amended from time to time, that sets out rights, duties and responsibilities of shareholders, directors and others within and in relation to a company, and other matters as contemplated in section $15 .^{2}$ The Companies Act allows a large degree of flexibility with regard to the content of the MOI. However, each provision of a company's MOI must be consistent with the provisions of the Act. ${ }^{3}$ The MOI can therefore determine the rights, powers and duties of stakeholders. ${ }^{4}$

However, a matter of concern that arises is, how, where a company's shareholders change their minds about the entity's social or environmental goals and vote to amend the $\mathrm{MOI}$, will the board be able to prevent the amendment? A

\footnotetext{
${ }^{1}$ Hereafter, the MOI. In terms of the Companies Act, the incorporators of a company now submit the MOI as the only founding document of the company. It is noteworthy that in terms of the Companies Act 1973, all companies were required to submit a memorandum and articles of association as the constitutive documents of a company formed under that Act. One could not incorporate a company unless these documents were submitted to the office of the registrar of companies.

2 Section 15 deals with the Memorandum of Incorporation, shareholder agreements and rules of company.

${ }^{3}$ Any provision that is inconsistent with the provisions of the Act will be regarded as void to the extent that it contravenes or is inconsistent with the Act.

${ }^{4}$ A company's $\mathrm{MOI}$ can deal with any number of different issues including the following; objects and powers of the company, authorized share capital and types of shares, the composition of the board of directors, the personal liability of directors, the rights of shareholders, the rights of stakeholders and the amendment of the MOI.
} 
social or environmental mission embodied in the $\mathrm{MOI}$ of a company can be easily amended or eliminated if the company is acquired by a majority of investors who do not have interests aligned with those of the company's stakeholders. A company's MOI can be amended inter alia "at any other time if a special resolution to amend it(i) is proposed by, (a)the board of the company; or(b)shareholders entitled to exercise at least $10 \%$ of the voting rights that may be exercised on such a resolution; and(ii) is adopted at a shareholders meeting ...." ${ }^{5}$ Thus, there exists the possibility for companies to easily amend the original $\mathrm{MOI}$ to pursue goals not in the best interests of the original stakeholders should there be a need to attract outside investors and investment capital.

\section{The Argument on the Business Judgment Rule}

The business judgment rule ${ }^{6}$ is found in section 76(4) of the Companies Act. The business judgments rule has been incorporated into the South African company law as part of the statement on the duty to act in the best interest of the company ${ }^{7}$ and with care, skill and diligence. ${ }^{8}$ In terms of the rule, a director will be protected from allegations of breach of the duty to act in the best interests of the company and with care, skill and diligence in relation to a matter where that director has (i) taken reasonably diligent steps to become informed about the matter, (ii) either had no conflict of interest in relation to the matter or complied with the rules on conflict of interests and (iii) had a rational basis for believing, and did believe, that his decision was in the best interest of the company. ${ }^{9}$ The business judgment rule therefore becomes a shield for directors against liability imputations. ${ }^{10}$ The rule is a 'standard of non-review of the merits of a business decision corporate officials have made.'11The business judgment rule is intended to further the objective of the Act, succinctly described by Davis et al, ${ }^{12}$ as follows:

Read as a whole, the 2008 Act promotes the objective that there should not be an over-regulation of company business. The Act grants directors the legal authority to run companies as they deem fit, provided that they act within the legislative framework. In other words, the Act tries to ensure that it is the board of directors, duly appointed, who run the business rather than regulators and judges, who are never best placed to balance the interests of shareholders, the firm and the larger society within the context of running a business.

The business judgment rule has played an important role in expanding director discretion to allow for consideration of the interests of other stakeholders other than shareholders. The rule developed, in part, due to judicial reluctance to interfere ex post with board decisions. Given the difficult nature of the determinations that directors make, and the potential for hindsight bias, the Act has given deference to directors provided they inter alia had a rational basis for believing, and did believe, that their decision was in the best interest of the company. ${ }^{13}$ The impact of the business judgment rule is to insulate board decisions from court scrutiny. Business judgment deference gives directors wide discretion to make decisions that may in fact advance the interests of one group of stakeholders over another.

However, a matter of concern arises is whether the business judgment rule protects director's decisions that

\footnotetext{
${ }^{5}$ See section 16(1).

${ }^{6}$ The business judgment rule was developed in the United States of America (USA) alongside the duty of care and relates to one aspect of this duty, namely that of decision-making. In the USA, the business judgment rule as a common law principle can be traced as far back as 1829 - see Percy v Milledon 8 Mart (NSW) 6878 (La 1829).

7 Section 76(3)(b). This duty exists by virtue of the special relationship that exists between the director and the company, namely the fiduciary relationship. The basis on which a director is held liable by his company for a breach of his fiduciary relationship is the general principle that a person standing in a fiduciary relationship to another commits a breach of trust if he acts for his own benefit or to the prejudice of that other. The cause of action is neither delictual nor contractual but one that is based on breach of trust (Robinson $v$ Randfontein Estates Gold Mining Co Ltd 1921 AD 168). See Benade et al Entrepreneurial Law (2009) 131.

${ }^{8}$ Section 76(3)(c). A director who does not observe his duties of care and skill towards his company is liable to it in delict for damages. If in addition there had been a contract between the director and his company, as is usually the case with full-time directors, he could be guilty of breach of contract as well.

${ }^{9}$ Section 76(4).

10 The rationale being to promote innovation by providing the right balance between the competing interests of commercial risk taking by directors and, on the other hand, their accountability.

11 Branson D.M. "The Rule That Isn't a Rule - The Business Judgment Rule," (2002) 36 Val. U.L.Rev.631; lan D "Delivering the Judgment on Statutory Business Judgment Rule In Australia" 1995 Australia Journal of Corporate Law 422; Larelle L "The Business Judment Rule In Australia: A Re-Appraisal Since the AWA Case" (1997) Company and Securities LJ 174; see also Harold Co v Seawell 472 F 2d 1081 (10th Cir 1972); Financial Industrial Fund Inc v McDonnell Douglas Corp 474 F 2d 514 (10th Cir 1973); Wolf v Fried 473 Pa 26373 A. $2 d 734$ (1977); Shlensky v Wrigley 95 III App 2d 173237 NE 2d 776 (1968).

12 Davis et al Companies and other Business Structures in South Africa (2010) 16.

${ }_{13}$ Section 76(4).
} 
favours stakeholders but are to the detriment of shareholders. This issue emanates from the fact that the Companies Act does not does not provide clarity on what is meant by the best interests of the company. In line with the wording in section 76(3)(b), section 76(4)(iii) simply states that the director must inter alia have rationally believed that the decision was in the best interests of the company. Unfortunately, understanding whether a decision was in "the best interests of the company" may be a more difficult task.

\section{The Argument on the Link between Good Corporate Governance Principles and the Law}

While the Companies Act does not provide guidance on what is meant by the 'best interests of the company, one may argue that the 'best interests of the company' must be interpreted in the context of King III which favours the stakeholder approach. In other words, the courts should use King III as a tool to assist in the interpretation of the Companies Act. A matter of concern that immediately arises is on what basis should the courts use King III to interpret the Act. It is noted that section 5 of the Act, which deals with the rules regarding the general interpretation of the Companies Act does not expressly provide for the use of corporate governance codes such as King III when interpreting the Act. However, one may still argue that section 5 of the Act must be interpreted within a broader context.

Section 5(1) provides that the Companies Act must be interpreted and applied in a manner that gives effect to the purposes set out in section 7. Section 7 provides inter alia that one of the purposes of the Act, 'to promote the development of the South African economy by encouraging transparency and high standards of corporate governance as appropriate, given the significant role of enterprises within the social and economic life of the nation. ${ }^{14}$ Another identified purpose of the Act is that of reaffirming the concept of the company as a means of achieving economic and social benefits. ${ }^{15} \mathrm{~A}$ broader interpretation of section $5(1)$ read together with section 7 therefore, appears to allow the use of corporate governance codes as a tool in interpreting the Act. Reliance by the courts on King III is undeniably pivotal if the Companies Act is to be interpreted in a manner that promotes the development of the economy by encouraging transparency and high standards of corporate governance. The corporate governance codes serve a crucial role in promoting good corporate governance in South Africa alongside compliance with the law.

However, despite this link between corporate governance and the law, it is arguable whether the courts will be keen to hold directors liable on the grounds of failure to adhere to voluntary corporate governance codes of practice. King III is based on the "apply or explain" principle, and finding liability on the part of the director who fails to consider corporate governance practices will be a daunting task for the courts. This is because, should directors believe that to follow a King III recommendation would not be in the best interests of the company and thus apply a different approach or deviate slightly from the recommendations, then by explaining how the recommendation were applied or the reasons for applying a different approach would result in compliance. In this light, the shortcoming of King III is therefore that it holds no legal enforcement of duties over directors or offer any form of remedy that stakeholders can rely on to pursue any prejudice directed at them

This voluntary nature of the corporate governance codes may account for the relative paucity of cases where courts have relied on corporate governance. In fact, in some cases where the opportunity to consider corporate governance arose, the courts simply chose not to consider that notion. For instance, in the case of Triptomania Twee (Pty) Ltd and Others $v$ Connolly And Another ${ }^{16}$ the applicants attacked the emphasis which King II placed on the role of the board of directors in general and the role of non-executive directors in particular, by stating that the emphasis in the King II was misplaced. The court came to certain conclusions on the facts and did not consider the above mentioned contentions of the applicants. Similarly, in De Villers and Another NNO v BOE Bank Ltd, ${ }^{17}$ the advocates of the parties relied on King II in support of certain arguments but the court did not refer to or deal with King II in the judgment in any way.

However, in the case of the Minister of Water Affairs and Forestry v Stilfontein Gold Mining Co. Ltd \& Others ${ }^{18}$ the court relied extensively on King II. In this case, the applicant (the Minister of Water Affairs and Forestry) obtained a provisional court order with regard to environmental requirements against the first respondent (Stilfontein Gold Mining Co. Ltd) and second to fifth respondents (directors of Stilfontein Gold Mining Co. Ltd) which the respondents had to adhere to. In an attempt to escape the consequences of this court order, the whole board of the first respondent

\footnotetext{
14 See section 7(b)(iii).

15 See section $7(d)$.

16 Triptomania Twee (Pty) Ltd and Others v Connolly And Another 2003 (3) SA 558 (C).

${ }_{17}$ De Villers and Another NNO v BOE Bank Ltd 2004 (3) SA 1 (SCA).

${ }^{18}$ Minister of Water Affairs and Forestry v Stilfontein Gold Mining Co. Ltd 2006 (5) SA 333 (W).
} 
resigned, leaving the first respondent unable to comply with the court order, and leaving the applicant in a dilemma since at the time that the application was brought, the second to fifth respondents (the previous members of the board of the first respondent) were no longer the board members of the first respondent. The court inter alia held that a director of a company who, with knowledge of an order of court against the company, causes the company to disobey the order is himself guilty of contempt of court. ${ }^{19}$ The court further held that the Code of Conduct of King II was almost uniformly endorsed by the corporate community in South Africa and that the conduct of the respondent directors flew in the face of everything recommended in the code of corporate practices and conduct recommended by the King Committee. ${ }^{20}$

\section{The Argument on the Social and Ethics Committee}

Section 72(4)(a) of the Companies Act authorizes the Minister of Trade and Industry to prescribe through the use of regulations, that a company or category of companies described in terms of their annual turnover, the size of their workforce and the nature and extent of their activities must have social and ethics committees. The Minister acted on this mandate and on 26 April 2011 the Companies Regulations, 2011 were released which inter alia introduced the new requirement that companies falling within a certain category must establish a social and ethics committee. In terms of regulation 43(1) of the Companies Regulations, companies that are state-owned, listed public companies or companies that have in any two of the previous five years scored over five hundred points in terms of regulation $26(2)^{21}$ must appoint a social and ethics committee. ${ }^{22}$ The committee must consist of not less than three directors or prescribed officers of the company. ${ }^{23}$ At least one of these directors or prescribed officers must be a director not involved in the day-to-day management of the company and who has not been so involved in the preceding three years. ${ }^{24}$

In terms of regulation 43(5)(a), the function of the committee is to monitor the company's activities, having regard to any relevant legislation, other legal requirements or prevailing codes of best practice. This relates to matters concerning, social and economic development, including the company's position regarding the goals and purposes as envisaged in, for example, the OECD Principles and the Global Compact Principles ${ }^{25}$ and good corporate citizenship, including the company's contribution to the development of communities in which its activities are predominantly conducted or within which its services are predominantly marketed ${ }^{26}$ as well as record of sponsorships, donations and charitable giving. ${ }^{27}$ The committee should also report annually to the shareholders at the company's annual general meeting on the matters within its mandate.

With the implementation of section 72(4), it appears there is an attempt to incorporate the interests of the various stakeholders in the Companies Act. However, a matter of concern that arises is that while the Companies Act makes it clear that the power to appoint members of the committee vests with the board unless otherwise provided in the company's Memorandum of Incorporation, it does not specifically require the board to include stakeholder representatives in the committee. ${ }^{28}$ The requirement to include stakeholder representatives would ensure that the committee actively engages with its stakeholders thereby guaranteeing the adequate protection of stakeholders' interests. In this regard, it is submitted the Companies Act should explicitly require the inclusion of stakeholder

\footnotetext{
${ }^{19}$ Minister of Water Affairs and Forestry $v$ Stilfontein Gold Mining Co. Ltd, para 16.8.

${ }^{20}$ Minister of Water Affairs and Forestry $v$ Stilfontein Gold Mining Co. Ltd, para 16.7.

${ }^{21}$ Regulation 26(2) states that: 'For the purposes of Regulations 27 to 30, 43, 127 and 128, every company must calculate its 'public interest score' at the end of each financial year, calculated as the sum of the following: (a) a number of points equal to the average number of employees of the company during the financial year; (b) one point for every R1 million (or portion thereof) in outstanding unsecured debt of the company, at the financial year end; (c) one point for every R1 million (or portion thereof) in turnover during the financial year; and (d) one point for every individual who, at the end of the financial year, is known by the company - (i) in the case of a profit company, to directly or indirectly have a beneficial interest in any of the company's issued securities; or (ii) in the case of a nonprofit company, to be a member of the company, or a member of an association that is a member of the company.'

22 These companies must appoint a social and ethics committee unless exemption has been in terms of section 72(5) and (6) of the Companies Act or unless the company is a subsidiary of another company which has a social and ethics committee and which will perform the functions required by the Companies Regulations, 2011 on behalf of the subsidiary company - regulation 43(2)(a).

${ }_{23}$ See regulation 43(4).

24 See regulation 43(4).

25 See regulation 43(5)(a)(i)(aa) and (bb). The incorporation of the UN Global Compact and the OECD requirements, which are voluntary standards in other jurisdictions, into local corporate law is note worthy.

26 See regulation 43(5)(a)(ii)(bb).

27 See regulation 43(5)(a)(ii)(bcc).

${ }^{28}$ See section 72(1) and (2).
} 
representatives in the committee. Furthermore, by omitting to give stakeholders rights which they can enforce, the Companies Act fails to adequately protect the interests of the stakeholders. Thus, as a result the provisions of section 72(4)-(10) and regulation 43 are unenforceable by stakeholders, unless they are able to rely on some form of action, such as the derivative action as provided for in terms of the Act. However, protection of stakeholders' interests in terms of the derivative action is also problematic as will be highlighted in the following discussion.

\section{The Argument on Remedies}

The Companies Act provides for rights to seek specific remedies. ${ }^{29}$ The remedies are aimed at discouraging gross mismanagement and abuse of power, and to uphold the enforcement of stakeholder rights. ${ }^{30}$ Of particular interests are the rights of stakeholders in terms of section 165(2) to seek specific remedies. ${ }^{31}$ The section provides for the statutory derivative action. ${ }^{32}$ The statutory derivative action allows certain specified persons to institute proceedings on behalf of a company where the company has been prejudiced by acts of its controlling directors and where the company has failed to take the necessary action to call these directors to account.

Section 165(2) provides that the persons who may use the statutory derivative action are (essentially) a shareholder, a director, a representative of employees or any other person with leave of the court. ${ }^{33}$ Section 165(2)(d) provides that a person may serve a demand upon a company to commence or continue legal proceedings or to take related steps, to protect the legal interests of the company if the person has been granted leave of the court to do so. However, such granting of locus standi to other stakeholders is left to the discretion of the court. Ultimately, if the stakeholders can prove to the court's satisfaction that they have locus standi to bring a demand to institute a derivative action and that it is in the best interests of the company to do so, then such court has no other alternative but to grant such leave. However, a court will only grant such leave upon compliance by the company with one of the factors stated in section 165(5) of the Companies Act.

In light of this probable recognition of other stakeholders, it must not be forgotten that the ultimate purpose of the derivative action is to protect the legal interests of the company and not the legal rights of other stakeholders. As Cassim et al contend, the intention of section 165 may be to allow courts to grant standing to stakeholders whose legal rights are indirectly affected due to an infringement of the company's legal interests. ${ }^{34}$ Section $165(2)$ (d) allows the possibility of legal recognition for stakeholders' rights, including effective enforcement of such rights should they prove to have locus standi. If such standing is successfully proved and depending on the discretion of the court, then stakeholders can be said to have an effective action against management if their rights have been prejudiced. However, as mentioned, it must be kept in mind that the purpose of the statutory derivative action is to provide for the interests of the company and not the interests of the stakeholders.

\section{Conclusion}

In excluding other stakeholders from explicit consideration or integration, South African company law privileges the interests of shareholders over all others. It is true that the law requires directors to act in the best interest of the company, ${ }^{35}$ not the shareholders directly. It is also the case that particular company law principles such as the business

\footnotetext{
${ }^{29}$ See Part B Chapter 7 sections 160-165.

30 Davies et al, Companies and Other Business Structures in South Africa 2011269.

${ }^{31}$ It is noteworthy that while Part B Chapter 7 sections 160-165 of the Companies Act provides rights to specific remedies, these rights are extended to other stakeholders in sections 162 and 165. In terms of section 162(2), a shareholder, director, company secretary or prescribed officer of a company, a registered trade union that represents employees of the company or another representative of the employees of a company may apply to a court for an order declaring a person delinquent or under probation if inter alia the person is a director of that company. This section will not be discussed as it does not further the interests of stakeholders per se. Focus will be on section 165. Section 161, section 163 and section 164 specifically deals with rights of shareholders to specific remedies and therefore not dealt with as the argument is to show situations in the Act where stakeholders (not just shareholders) are granted rights.

${ }^{32}$ See generally the following cases that shed light on the derivative action; Foss v Harbottle 18432 Hare 461; McLelland v Hulett 1992 (1) SA 456 (D); and Thurgood v Dirk Kruger Traders (Pty) Ltd 1990 (2) SA 44 (E).

${ }_{33}$ See further section 165(2) read with section 157(3) and 165(16) of the Companies Act.

${ }^{34}$ Cassim FHI, Cassim MF, Cassim R, Jooste R, Shev J and Yeats J Contemporary Company Law 2011703.

${ }^{35}$ See Robinson v Randfontein Estates Gold Mining Co Ltd AD 168; Atlas Organic Fertilisers (Pty) Ltd v Pikkewyn Ghwano (Pty) Ltd [1981] (2) SA 173 (T) 197; Sibex Construction (SA) Pty Ltd v Injectaseal CC 1988 (2) SA 54 (T); CyberScene Ltd v i-Kiosk Internet and Information (Pty) Ltd 2000 (3) SA 806 (C); Phillips v Fieldstone Africa (Pty) Ltd [2004] 1 All SA 150 (SCA);Regal (Hastings) Ltd v
} 
judgment rule afford directors broad deference deciding how to further these interests. As a practical matter, then, directors can and do consider the interests of other stakeholders in making their decisions. However, they do not have to and it would be an overstatement to suggest that directors could opt to serve other interests to the exclusion of shareholder interests. It is in this regard that it is submitted that the shortcoming of the Companies Act lies in the failure to provide directors with an explicit duty to consider the interests of stakeholders in their decision making. Thus, stakeholders are not afforded direct rights in terms of the Companies Act. As a result of this, stakeholders' interests are not adequately protected in the Act.

\section{References}

Benade, M. L., J. J. Henning, J. J. Du Plessis, P. A. Delport, L. De Koker \& J. Pretorius (2008). Entrepreneurial Law. Special ed. Durban: LexisNexis.

Cassim FHI, Cassim MF, Cassim R, Jooste R, Shev J and Yeats J Contemporary Company Law 2011703.

Davies D, Cassim F, Geach W, Mongalo T, Butler D, Loubser A, Coetzee L and Burdett D, Companies and Other Business Structures in South Africa $2^{\text {nd }}$ Edition (2011) Oxford University Press Southern Africa.

Esser I, "A global perspective on African Corporate Governance: the protection of stakeholders' interests" (2007) 32 South African Yearbook of International Law: Good Governance \& Non-state Actors in International Law: an African Perspective: Regional Conference $406-429$

Esser I, "Stakeholder Protection: The Position of Employees" (2007) 70 TydskrifvirHedendaagseRomeins-HollandseReg 407.

Esser I, "The Protection of Stakeholder Interests in Terms of the South African King III Report on Corporate Governance: An Improvement on King II?" (2009) 21 SA Merc LJ 188-201.

Esser I and Dekker A, "The Dynamics in Corporate Governance in South Africa: Broad Based Black Economic Empowerment and the Enhancement of Good Corporate Principles" (2008) 3(3) J. of Int. Commercial Law and Technology 157.

Esser I and Du Plessis JJ, "The Stakeholder Debate and Directors' Fiduciary Duties" (2007) 19 SA Merc LJ 346.

Havenga M, "The Company, the Constitution and the Stakeholders" (1997) 5 Juta BusinessLaw Journal 134-139.

Hendrikse JW and Hefer-Hendrikse L Corporate Governance Handbook $2^{\text {nd }}$ Edition 2004 Juta\& Co. Ltd.

Ho VEH, "Enlightened Shareholder Value: Corporate Governance Beyond the Shareholder-Stakeholder Divide" 2010 36(1) The Journal of Corporation Law 59.

Gulliver [1942] 1 All ER 378 (HL); Magnus Diamond Mining Syndicate v Macdonald \& Hawthorne [1909] ORC 65; Industrial Developments Consultants Ltd v Cooley [1972] 2 All ER 162; Percival v Wright [1902] 2 CH 421; Multinational Gas and Petrochemical Co v Multinational Gas and Petrochemical Services Ltd [1983] Ch 258. 